\title{
Occurrence of Spontaneous Triploidy in Manihot esculenta Crantz
}

\author{
Reginaldo de Carvalho ${ }^{1 *}$, Marcelo Guerra ${ }^{1}$ and Paulo Cezar L. de Carvalho \\ ' Departamento de Botânica (CCB), Universidade Federal de Pernambuco, Recife-PE, 50670-901, Brasil \\ ${ }^{2}$ Departamento de Fitotecnia, Escola de Agronomia de Cruz das Almas, Cruz das Almas, Bahia, Brasil
}

Accepted January 5, 1999

\begin{abstract}
Summary The spontaneous occurrence of a triploid is reported in Manihot esculenta Crantz collected in Sapé-PB, Brazil. Mitotic analysis showed a stable chromosome number of $2 n=54$, with chromosome size and morphology very similar to the diploid species. The chromosome behavior in meiosis was irregular in the metaphase-anaphase I, with occurrence of uni, bi and trivalents. The average number of univalents per cell was 7.2. In the tetrad stage, a higher number of micronuclei were found, resulting in almost $100 \%$ of abnormal tetrads and pollen sterility. Triploid was also characterized by having larger and fewer stomata than diploid species.
\end{abstract}

Key words Manihot esculenta, Spontaneous triploidy, Microsporogenesis, Stomata.

Cassava (Manihot esculenta Crantz), is one of the most important crops in developing countries, since its root provides a valuable source of carbohydrate (Roca et al. 1991). Species of Manihot can be cultivated widely in all of the tropics and subtropics (Umanah and Hartmann 1973). Cassava cultivars are propagated only vegetatively by stem cuttings although they can produce viable seeds. The genus is native to America and species are found from the United States of America to Argentina (Rogers and Appan 1973, Pereira and Carvalho 1978). Central Brazil (South of Goiás and West of Minas Gerais) is the largest centre of diversification of the genus (Nassar 1978).

Cassava is generally considered as a species of allotetraploid origin with $2 n=36$ and base number $x=9$ (Perry 1943). However, like many other polyploid species, it has been "diploidized" during its evolution and now exhibits a chromosomal diploid behaviour (Singh 1993). Graner (1941) induced polyploidy in cassava by use of colchicine, obtaining 27 tetraploid clones $(2 n=4 x=$ $72)$ and a single octoploid $(2 n=8 x=144)$. The treatment was applied to the terminal part of the shoots so that the roots of the treated plants remained diploids. Hahn et al. (1990) reported the occurrence of tetraploids and triploids induced by interspecific crosses between a cultivar of $M$. esculenta and two of its related species, M. epruinosa and M. glaziovii. On the other hand, the occurrence of spontaneous polyploidy in cassava do not appear to be very frequent. The first report was made by Hahn et al. (1992), who found a tetraploid specimen with $2 \mathrm{n}=72$ among 11,480 plants of TMS 91934 clone.

Our aim is to report the occurrence of a natural triploid in Manihot and describe its cytogenetical characteristics, with emphasis on its microsporogenesis.

\section{Material and methods}

A clone of Manihot esculenta cultivar Manipeba, collected in Sapé, Paraíba, Brazil, was maintained in the germplasm bank of the School of Agronomy of Cruz das Almas, Bahia, and in the experimental garden of the Department of Botany of the Federal University of Pernambuco. The specimen grows in a clump of approximately $1.5 \mathrm{~m}$ of height, with narrow branches and leaves, and

\footnotetext{
* Corresponding author. E-mail: rcarvalho@npd.ufpe.br or rmanihot@hotlink.com.br
} 
flowers characteristic of M. esculenta. Fruits have not yet been found. Voucher specimen are deposited in the Federal University of Pernambuco herbarium (UFP).

Young root tips were obtained from cuttings, pretreated with 8-hydroxyquinoline $(0.002 \mathrm{M})$ for approximately $24 \mathrm{~h}$ at $8^{\circ} \mathrm{C}$, and fixed in ethanol-acetic acid $(3: 1, \mathrm{v} / \mathrm{v})$. Flower buds were fixed in $3: 1$ ethanol:acetic acid during $2-24 \mathrm{~h}$ at room temperature. Cytological preparations were made following the method described by Guerra (1983). Root tips were washed in distilled water, hydrolyzed in $5 \mathrm{~N} \mathrm{HCl}$ for $20 \mathrm{~min}$ at room temperature, squashed in a drop of $45 \%$ acetic acid and stained with a $2 \%$ Giemsa solution. Chromosome measurements were taken from the five best mitotic cells.

For meiotic analysis, flower buds were hydrolyzed in $5 \mathrm{~N} \mathrm{HCl}$ for $5 \mathrm{~min}$. The anthers were isolated and squashed in $45 \%$ acetic acid, and stained with $1 \%$ hematoxylin. Tetrad analysis was made in phase contrast and the pollen fertility was observed with $2 \%$ acetocarmine staining. The distribution and size of stomata were observed from the impressions on a thin film of transparent enamel applied to the surface of the leaf (Bai and Jos 1981), and photographed in phase contrast. In order to compare the normal frequencies of tetrads and viable pollen grains, the Manipeba cultivar and the diploid cultivar Najá obtained from the National Research Center for Cassava and Tropical Fruit Crops (CNPMF), EMBRAPA, BA, Brazil, was also analysed. Photographs were taken with Leica DMRB microscope using Imagelink HQ 25 ASA film and Kodabromide Kodak F3 paper.

\section{Results and discussion}

The Manipeba cultivar showed only triploid cells with $2 n=54$ (Fig. 1). All chromosomes were metacentric to submetacentric, and very similar in morphology and size to the diploid cultivar analysed. Measurements made in metaphase mitotic chromosomes of triploid clone showed an average length of $1.75 \mu \mathrm{m}$ with a range of $1.12 \mu \mathrm{m}$ to $2.53 \mu \mathrm{m}$. The total length of somatic chromosome complement was $94.38 \mu \mathrm{m}$ or $31.49 \mu \mathrm{m}$ per monoploid set. These measurements agree with those of some diploid cultivars of $M$. esculenta and other species of the genus previously analyzed in our laboratory (unpublished results). Nevertheless, Umanah and Hartmann (1973) analyzed untreated mitotic cells of other $M$. esculenta varieties with less condensed chromosomes and found a mean length of $2.5 \mu \mathrm{m}$, ranging between 1.6 and $4.0 \mu \mathrm{m}$.

Meiotic behavior of the triploid was quite irregular showing univalent, bivalent and trivalent in metaphase I (Fig. 2). The number of univalents varied from 4 to 10, with a mean of 7.2 in the 16 cells analyzed. The chromosome disjunction in anaphase I and II was also irregular, resulting in a very reduced number of normal tetrads. From 706 groups of cells in the tetrad stage, only eight $(1.13 \%)$ exhibited a normal set of four cells. The highest frequencies observed were of groups with seven $(22.95 \%)$ and eight (22.66\%) cells. Moreover, $12.18 \%$ of the "tetrads" had six cells, $15.86 \%$ nine cells, and $25.22 \%$ had 10 to 13 cells, against $100 \%$ of normal tetrads in the diploid Najá cultivar (Fig. 3). Similarly, Graner (1942) analyzed flower buds of the tetraploid and octoploid clones and found polyads with up to eight cells, four cells larger and other very small.

Mature anthers presented pollen grains of several sizes (Fig. 4). The stain of the pollen grains with acetocarmine showed $100 \%$ of them lightly stained suggesting total sterility. Hahn et al. (1990) observed a smaller frequency of viable grains in the triploid (10.5 to $11.6 \%)$ and tetraploid (48.6 to $64.7 \%$ ) cassavas than in the diploid ones (75.1\%). On the other hand, Graner (1942) found $50 \%$ of viable pollen grains in diploid cassavas against $80 \%$ of viability in tetraploids. The divergence in pollen viability observed between diploids and tetraploids could be due to differences in the genotypes investigated. In this case, it is possible that triploids also show different fertility indexes. The triploids are somewhat more robust and vigorous than normal diploids, but are less than $2 \%$ fertile (Harlan and deWet 1975). The data of the present work are in agreement with the observed general tendency for triploids to have low fertility (Singh 1993). 

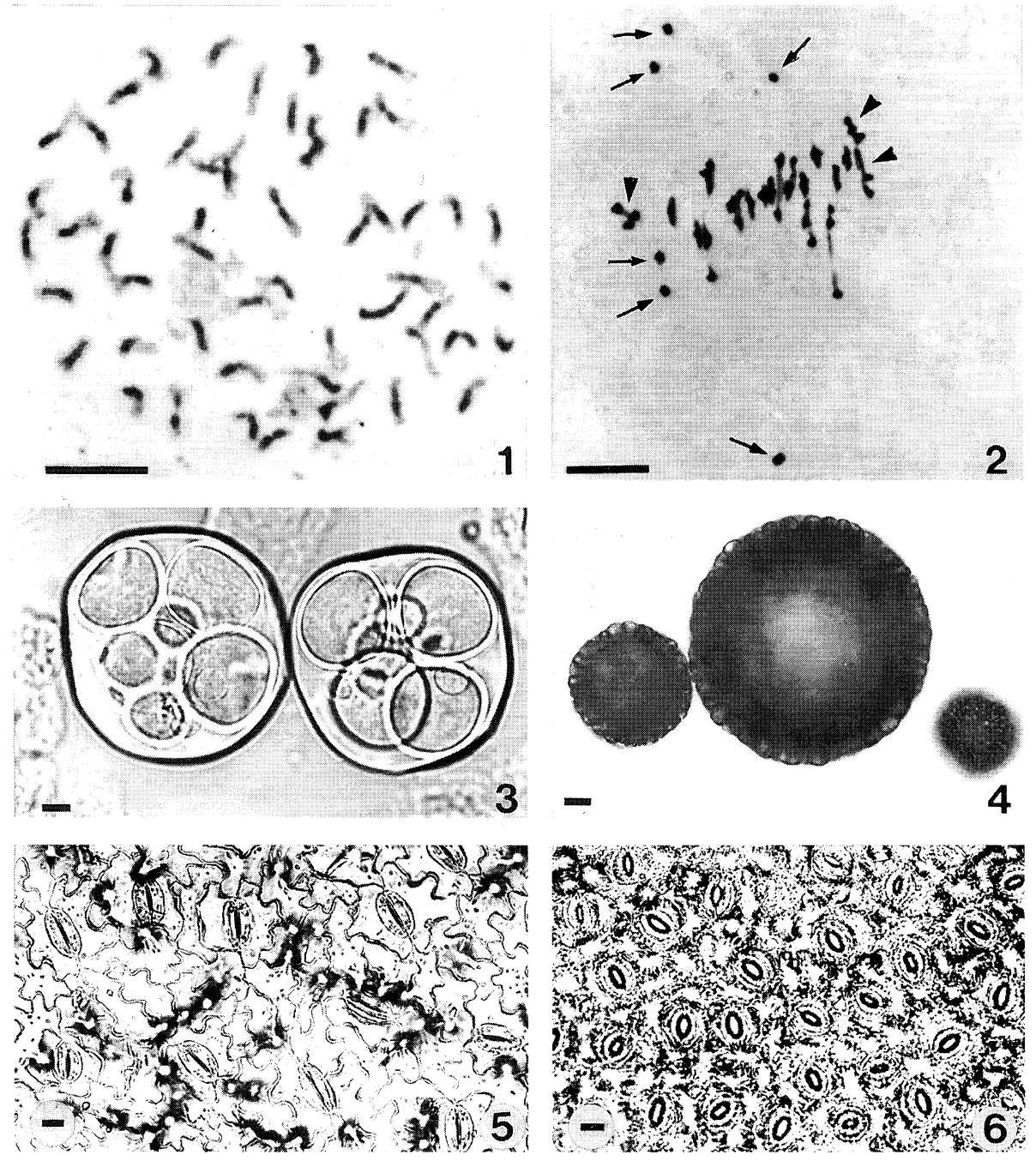

Figs. 1-6. Chromosomes, "polyads" and pollen grains of M. esculenta cultivar Manipeba (1-4) and stomata of triploid and diploid cultivars (5-6). 1) Mitotic prometaphase with $2 n=54$. 2) Meiotic metaphase I showing univalents (arrows) and trivalents (arrow heads). 3) Abnormal tetrads with 10 and 9 cells. 4) Sterile pollen grains. 5) Closed stomata of 'Manipeba' 6) Open stomata of 'Najá'. Bar represents $10 \mu \mathrm{m}$.

Graner (1942), reported a positive and significant correlation between stomata size and chromosome numbers, suggesting that stomata size can be taken as good poliploidy indicator, except for chimerical plants. Similarly, Hahn et al. $(1990,1992)$ observed that in triploid and tetraploid cassavas, the stomata size was larger and the number of stomata per unit leaf area was smaller than in diploids. The triploid clone analyzed in this work presented a lower number of stomata (148.6 for $\mathrm{mm}^{2}$ ) for leaf area and a larger size $(27.63 \mu \mathrm{m})$ (Fig. 5) compared to the Najá cultivar (285.3 for $\mathrm{mm}^{2}$ and $18.9 \mu \mathrm{m}$ ) (Fig. 6). The latter observation agrees with measurements made in other diploids registered in the literature. These observations suggest that recognition of poliploid cassavas can be estimated directly by stomata density and stomata size. In other crop species the relationship between ploidy level and stomata density or stomata size has not always been found (Raman et al. 1971).

Spontaneous poliploids are not rare, but their maintenance in nature depends on their vigor 
and their capacity to compete with related diploids. The origin of the investigated triploid may be due to occasional seed propagation and selection. The potential of cassava poliploids as new cultivars and their use in genetic breeding program seems to be a resource still to be explored, mainly because of the high genetic variability of this genus has and its vegetative propagation (Hahn et al. 1990). The Manipeba cultivar is particularly important due to its high starch production and drought resistance even in sandy coastal regions and in the "chapadas" of Northeast Brazil (Braga 1953). Triploids, such as this can also be important for obtaining aneuploids for genetic mapping (Singh 1993) and to increase productivity (Nassar et al. 1996).

\section{Acknowledgements}

We are very grateful to André Laforga Vanzela and Gianna Carvalheira for correcting the English manuscript. This work was supported by FACEPE (Fundação de Amparo à Ciência e Tecnologia do Estado de Pernambuco), CNPq (Conselho Nacional de Desenvolvimento Científico e Tecnológico) and BNB (Banco do Nordeste do Brasil).

\section{References}

Bai, K. V. and Jos, J. S. 1981. A simple and rapid method of screening stomatal distribution and trichomes in cassava. Curr. Sci. 50: 773-774.

Braga, R. 1953. Plantas do Nordeste Especialmente do Ceará. (4 ${ }^{\mathrm{a}}$ edição), Editora universitária UFRN, coleção mossoroense. 315: pp. 540.

Graner, E. A. 1941. Polyploid cassava: Induced by colchicine treatment. Heredity. 32: 281-288.

- 1942. Tratamento da mandioca pela colchicina. Bragantia. 2: 23-54.

Guerra, M. S. 1983. O uso do Giemsa na citogenética vegetal: comparação entre a coloração simples e o bandeamento. Ciên. e Cult. 35: 190-193.

Hahn, S. K., Bai, V. K. and Asiedu, R. 1990. Tetraploids, triploids, and 2n pollen from diploid interspecific crosses with cassava. Theor. Appl. Genet. 79: 433-439.

- - - and - 1992. Spontaneous somatic tetraploids in cassava. Japan. J. Breed. 42: 303-308.

Harlan, J. R. and deWet, J. M. J. 1975. On Ö Winge and a player: The origins of polyploidy. Bot. Rev. 41: 361-390.

Nassar, N. M. A. 1978. Chromosome number and meiotic behaviour of some wild Manihot species native to Central Brazil. Braz. J. Genet. 1: 51-55.

-, Nassar, H. N. and Carvalho, C. G. 1996. Induction of the productive aneuploid in cassava, Manihot esculenta Crantz. Braz. J. Genet. 19: 123-125.

Pereira, S. C. and Carvalho, D. A. 1978. Botânica da mandioca (Manihot esculenta Crantz). ESAL-LAVRAS. 2: 18.

Perry, A. B. 1943. Chromosome number and phylogenetic relationships in the Euphorbiaceae. Amm. Bot. 26: 352-360.

Raman, V. S., Rangasamy, S. T. and Manimekalai, G. 1971. Triploidy and seedlessness in Guava (Psidium guajava L.). Cytologia 36: 392-399.

Roca, W. M., Arias, D. I. and Chávez, R. 1991. Metodos de Conservación "in vitro" del Germoplasma. In: Roca, W. M. and Mroginski, L. A. (eds.) Cultivo de Tejidos en la Agricultura: Fundamentos y Aplicaciones. pp. 698-713. Ciat, Cali.

Rogers, D. J. and Appan, S. G. 1973. Manihot, Manihotoides (Euphorbiaceae). In: Flora Neotropica-Monograph N ${ }^{\circ} 13$, pp. 272. Hafner Press, New York.

Singh, R. J. 1993. Plant Cytogenetics. pp. 111-254. CRC Press, Inc. Boca Raton.

Umanah, E. E. and Hartmann, R. W. 1973. Chromosome numbers and karyotypes of some Manihot species. J. Am. Soc. Hort. Sci. 98: 272-274. 